\title{
Mediastinal Lymphoma
}

National Cancer Institute

\section{Source}

National Cancer Institute. Mediastinal Lymphoma. NCI Thesaurus. Code C6633.

A lymphoma that arises from the mediastinum. Representative examples include mediastinal (thymic) large B-cell lymphoma and Hodgkin lymphoma. 